Електронне наукове фахове видання "Ефективна економіка" включено до переліку наукових фахових видань України з питань економіки (Категорія «Б», Наказ Міністерства освіти і науки України від 11.07.2019 № 975) www.economy.nayka.com.ua | № 5, 2021 | 27.05.2021 p.

DOI: $\underline{10.32702 / 2307-2105-2021.5 .4}$

UDC 338.984

K. Bogatyrev

Doctor of Economic Sciences, Professor, Professor of the Department of Theory and Methods of Physical Culture and Sports Disciplines, State Institution "South Ukrainian National Pedagogical University named after K.D. Ushinsky», Odessa

ORCID ID: 0000-0003-0963-8417

A. Obozna

PhD in Economics, Associate Professor,

Associate Professor of the Department of Hotel, Restaurant and Tourism business, $V P$ "Mykolaiv branch of the Kyiv National University of Culture and Arts", Mykolaiv

ORCID ID: 0000-0002-7243-5105

H. Burdelna

PhD in Economics, Associate Professor, Associate Professor of the Department of Management, Petro Mohyla Black Sea National University, Mykolaiv

ORCID ID: 0000-0003-0795-5961

I. Savarina

PhD in Economics, Associate Professor, Associate Professor of the Department of Management, Petro Mohyla Black Sea National University, Mykolaiv

ORCID ID:0000-0002-8952-3515

\title{
ASSESSMENT OF PROFESSIONAL AND PERSONAL COMPETENCES OF MANAGERS IN MANAGEMENT ACTIVITY
}

\author{
К. О. Богатирьов,
}

д. е. н., професор, професор кафедри теорії і методики фізичної культури та спортивних дисииплін, Держсавний заклад «Південноукраїнський начіональний педагогічний університет імені К. Д. Ушинського», м. Одеса

А. О. Обозна,

к. е. н., доцент з/н, дочент з/н кафедри готельно-ресторанного і туристичного бізнесу,

ВП «Миколаївська філія Киїського національного університету культури і мистецтв»,

м. Миколаїв

Г. О. Бурдельна,

к. е. н., дочент, дочент кафедри менеджменту,

Чорноморський національний університет імені Петра Могили, Миколаїв

І. П. Саваріна,

к. е. н., доцент (б.в.з.), доцент (б.в.з.) кафедри менеджменту, Чорноморський національний університет імені Петра Могили, Миколаїв

\section{ОЦІНКА ПРОФЕСІЙНИХ ТА ОСОБИСТІСНИХ КОМПЕТЕНЦІЙ КЕРІВНИКІВ В УПРАВЛІНСЬКІЙ ДІЯЛЬНОСТІ}


Innovative policy in personnel management today is the main task for company executives. The manager needs to identify an innovative strategy that will improve the quality of corporate culture in business management in a competitive global economy.

The author's vision of a constructive approach to ensure the creative development of the organization is presented, namely, it is necessary to rethink and adjust the interaction of the whole company and each of its participants to transform corporate strategy, to implement new business models and innovative management processes - it gives flexibility to make key changes. which can lead to increased company productivity and competitive advantage.

Despite the existing diversity of scientific and practical approaches to the classification of competencies, each organization, as practice shows, develops its own models of competencies in the field of business management and team, which greatly helps in building the management process.

In the article, the authors argue that one of the main tasks of the leader is to find a way to effective relationships with the team: communication with staff, helping subordinates to resolve unclear issues in work processes and innovation of a flexible approach to management.

An assessment of the competitive strategy of professional and personal competencies is analyzed and provided to explain how managers can achieve greater success in management, using a combination of creativity with the features of analytical thinking.

With the development of technology and innovation, new trends in the transformation of competencies are emerging, which will allow companies to make the right decision taking into account the main risks in the conditions and market changes.

The article explores the tools in the management of the relationship between business owners and staff, voiced individual analytical approaches of domestic and foreign scientists-practitioners, who in their research are acquainted in detail with their developments and approaches.

Інноваційна політика в управлінні персоналом сьогодні $\epsilon$ головним завданням перед керівниками компаній. Менеджеру потрібно визначити інноваційну стратегію, яка буде підвищувати якість корпоративної культури в управлінні бізнесу в умовах конкурентної глобальної економіки.

Представлено авторське бачення конструктивного підходу для забезпечення креативного розвитку організачії, а саме, потрібно переосмислити та наладити взаємодію всієї компанії та кожного ї̈ учасника для трансформації корпоративної стратегії, для реалізачії нових бізнес-моделей та інноваційних процесів менеджменту - ие дає уявлення гнучкості до проведення ключових змін, що може привести до підвищення продуктивності компанії $i$ конкурентної переваги.

Незважаючи на існуюче різноманіття науково-практичних підходів до класифікації компетенцій, кожна організачія, як свідчить практика, розроблює власні моделі компетенцій у сфері управління бізнесом та командою, що дуже допомагає у побудові прочесу управління.

У статті авторами аргументовано, щзо однією з головних задач керівника є пошук шляху до ефективних відносин 3 колективом: комунікації з персоналом, допомога підлеглим $у$ виріменні незрозумілих питань у робочих процесах та інноващії гнучкого підходу при управлінні керівниитва.

Проаналізована та надана оиінка конкурентної стратегії професійних та особистісних компетенцій, щуоб пояснити, як керівники можуть досягне більшого успіху в управлінській діяльності, використовуючи поєднання творчості з особливостями аналітичного мислення.

У міру розвитку технологій $i$ інновацій зароджуються нові тенденції перетворень компетенцій, щзо дозволить компаніям прийняти правильне рімення з урахуванням основних ризиків в умовах и ринкових змін.

У статті досліджено інструменти управління взаємовідносин між власниками бізнесу та персоналом, озвучено індивідуальні аналітичні підходи вітчизняних та іноземних вченихпрактиків, які в своӥх дослідженнях детально знайомлять зі своїми розробками і підходами. 
Keywords: professional competencies, effective personnel management, corporate strategy, modern concepts of competencies, business models, competence.

Ключові слова: професійні компетениії, ефективне управління персоналом, корпоративна стратегія, сучасні концепиії компетенцій, бізнес-моделі, компетенція.

Formulation of the problem. One of the strategic tasks in the HR direction is the development of innovative strategies and tactics, the implementation of organizational reforms in order to effectively manage personnel.

In a competitive global economy, the use of theoretical and practical knowledge in personnel management, the ability to work in a team, be responsible for developing innovative processes and their implementation to form a competitive company in the labor market and a strong, professional team in the organization - it requires professional competence. Therefore, it is necessary to adhere to a number of criteria of "healthy business conduct", to build requirements and criteria that are related to the competence of the company's managers and their employees.

Analysis of recent research and publications. Many domestic and foreign scientific works were devoted to the study of the problem of personnel management, which include the following scientists: G. Schmidt, L. Balabanova, F. Khmil, S. Vovkanych, M. Vinogradsky, G. Dessler, A. Kolot, V. Kolpakov, D. Kotelnikov, O. Krushelnytska, Y. Polekha, S. Polyansky, J. Galbraith, G. Mintzberg, J. Pfeffer, S. Robbins, F. Herzberg, R. Stolberg.

Setting objectives. Managers in a period of global innovation change create a management subsystem that uses various methods of creative thinking and techniques to create conditions so that relationships within the company are purposefully built on friendship and diligence, where after discussions, constructive arguments and relevant examples can always reach consensus.

Over the last decade, professional roles in information technology have changed and continue to change, with the rapid advancement of technology and the emergence of many artificial intelligence platforms that facilitate the work of managers.

Presentation of the main research material. In recent years, the definition of "competence" proposed by the American researcher M. Spencer [1] has been used in business: "competence" is a basic characteristic of a person associated with effective and best performance of work, which is assessed on the basis of appropriate criteria. "

Conventional refresher courses, such as face-to-face activities or online training, are no longer sufficient to transfer the required competencies, as special knowledge is transferred in the first place. The development of cognitive, emotional and communicative competencies is of great importance for the company's employees. This is where Serious Games (SG) come to the rescue, as they can be used to develop the necessary skills [2]. "Serious games" are (digital) games that serve more than just entertainment "[2]. They offer the opportunity to try different alternatives in a risk-free environment and, thus, to acquire competencies through the accumulation of empirical knowledge [2].

According to the concept of the TUNING project, basic (general) competencies are divided into [3]: instrumental, interpersonal, systemic (Fig. 1).

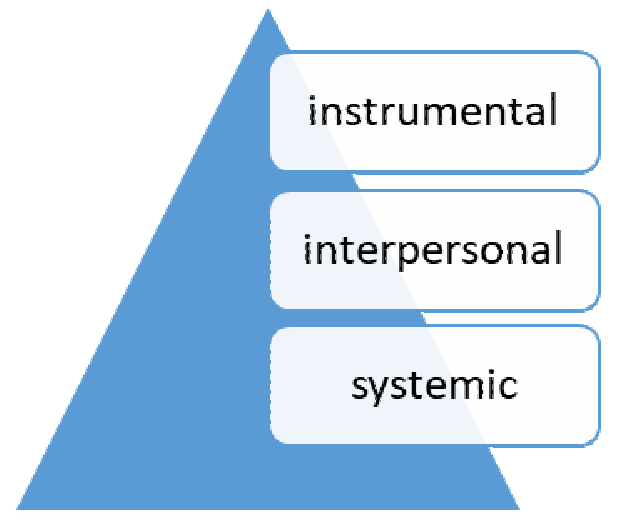

Fig. 1. General competencies according to the concept of the TUNING project [3]

Instrumental competencies include: analysis and synthesis; organization and planning; basic knowledge; information management; problem solving; decision-making.

Interpersonal competencies include: teamwork; critical thinking; intercultural communications; commitment to ethical values.

Systemic competencies include: systems thinking; application of knowledge in practice; ability to learn; ability to adapt to new conditions; leadership; ability to work autonomously; project development and management; initiative; responsibility for quality; focus on success.

As already mentioned, the use of a competent approach allows the employee to determine what exactly the management of the organization expects from his work. 
Strategic human resource planning aims to identify the right staff with the appropriate competencies needed to develop and implement new business models. Thus, it forms a relationship between innovation, corporate strategy and operational staff development.

To successfully achieve business goals and optimize business processes, it is important for leaders to apply new technologies and innovations in the work of the organization. The special role of personnel management is to identify the necessary personnel with the appropriate competencies. This includes rethinking the corporate orientation of the entire company and its members in the context of Industry 4.0 - the digital transformation of management into new innovative business model processes [4].

The Internet, artificial intelligence, large-scale globalization of digitalization of all industries - the number one trends in modern business. Along with them, another trend is developing - the issue of trust in technology. Technology not only serves as an auxiliary tool, and thus simplifies life, but also poses new challenges to society - a criterion of trust.

To better understand whether the following business processes need to be optimized, you need to pay attention to the following indicators (Fig. 2) [4]:

- staff growth in the company has increased sharply;

- the number of conflicts that can be resolved only with the involvement of management has increased (there are no uniform rules of the game);

- increased complaints from customers (for the service);

- disproportionate to the growth of business increased costs;

- there is a need to obtain quality certificates;

- there is an intention to automate their activities;

- chaotic document flow;

- no division of responsibilities ("hybrid staff");

- logistics does not keep up with sales;

- employees perform the same tasks differently.

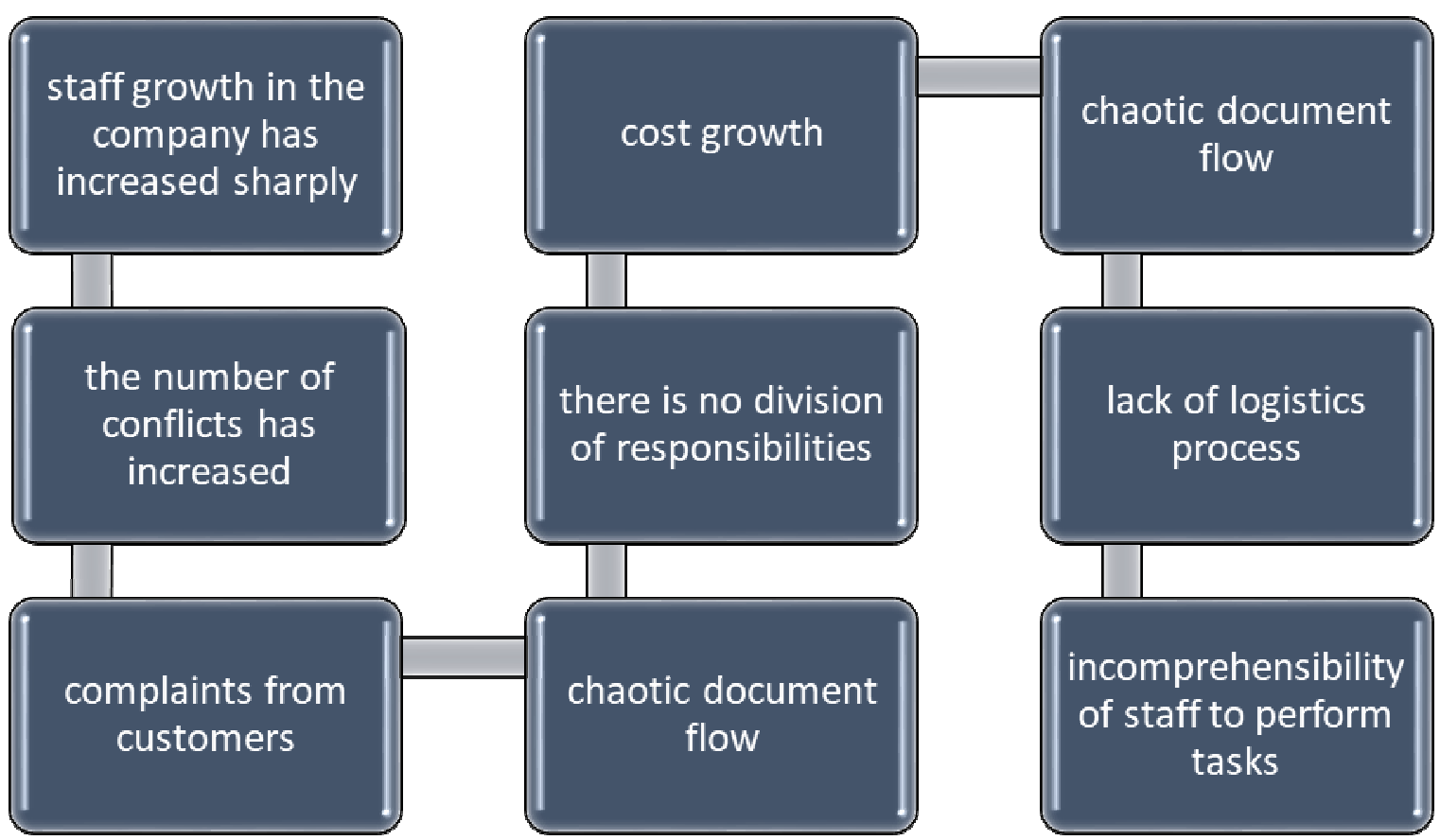

Fig. 2. Business Process Optimization Indicators [4]

Note that before starting work on the description and optimization of business processes, you need to clearly understand your goal. On the way to building a flexible company, it is possible to make mistakes in choosing an effective management style. The founders of companies are often from a team of large creative companies, so they used to work with professionals with extensive experience, so there was a need only to set goals - and everyone $90 \%$ knew what to do: build your workflow and measure your efficiency, and the most important thing is to be responsible for the result of your work.

We highlight the following main areas of innovative management activities of the head: decisions are made through meetings and discussions; managers try to do everything to make employees feel the microclimate in the workplace; system of bonuses and bonuses depending on results and professional skills; tuition fees (courses, seminars, workshops); "Creation of special moments" - encouragement to travel to the sea or abroad - to find creative inspiration, etc.

The importance of training in the process of effective team management. Trainings and courses in any field, especially in the field of business and team management, are very helpful in building the management process. But it is 
important to remember that you need to have a strong base, to engage in daily activities, where you need to train the acquired skills - this is self-education.

The main skills that a manager must have are knowledge of financial management, the ability to manage people, sell ideas and products and most importantly - be able to motivate.

For example, one of the most prominent ideal business leaders was Konosuke Matsushita, who began to implement the principles of corporate social responsibility [6]. Konosuke considered it important to understand the characteristics of each employee of the company, because without this understanding, successful business is impossible. "Failures as a necessity" can open new ways and perspectives. Konosuke Matsushita noted that "business is a team game" [6]. He singled out important competencies for each business leader (Fig. 3).

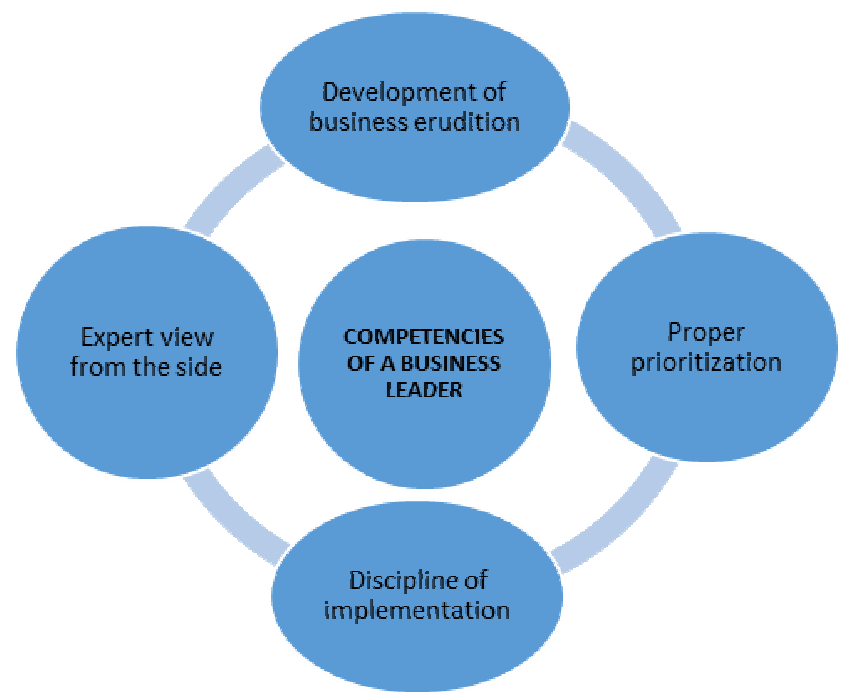

Fig. 3. Structural components of business leader competencies [6,7]

1. Development of business erudition. Owners or founders who have gained entrepreneurial experience in certain competencies in the past should remember that the acquired knowledge is imperfect, today it is necessary to pay attention to their regular updating to grow, develop and clearly understand new trends and take a strong position in the market.

The owner needs to build a strategy to promote modern and interesting forms of company work. If the owner understands what the right job is, then the right technical tasks will be set, and a qualified specialist will appear, and at the same time, the direction for movement and further growth will be determined.

Otherwise, if the entrepreneur, not understanding the principles of a process, relies on other people, the team will be the same incompetent professionals who will lead the business at best to achieve the goal a long way, at worst to bankruptcy.

\section{Correct prioritization.}

Entrepreneurs usually have a limited amount of resources - time and finances. With the right forecasting, the business develops effectively, with the wrong - the entrepreneur is immersed in current tasks and needs more time to develop new strategies. You need to learn to set priorities, the result of work depends on them, because the number of tasks may be the same, but with what sequence they will be performed, so will the result of the company - positive or negative.

\section{Discipline of implementation.}

Today, the observance of self-discipline by managers is important. Such a management system creates a consistent and time-adapted management structure, minimizing the risk of not fulfilling the planned tasks within the specified period.

\section{Expert view from the side.}

Entrepreneurs must be cheerful, enjoy the process, be multifunctional and think innovatively, following trends. But such components are interconnected, because the common values of the organization and synergy are an effective business management structure. The described business processes give the owner an understanding of how to develop a company, because he sees the full picture of his business and identifies both his strengths and weaknesses, which are worth working on [7].

The described business processes allow to free up time of employees for performance of creative and difficult tasks. Each member of the team will see not only their place, but also their own impact on the end result - to satisfy the client.

Summarizing the above - not only depends on the leader, how and how well the company will develop, the quality and integrity of the tasks of each team member depends on the successful outcome and success.

Conclusions. The success potential of the modern leader is [5]: 
1. Intellectual abilities: reason and logic; prudence; insight; conceptuality; business knowledge; language development; interest; intuitiveness; ability to learn; broad outlook.

2. Traits that characterize the personality: initiative; flexibility; creativity; honesty; courage and selfconfidence; independence; ambition; persistence and perseverance; energy; efficiency; obligatory; compassion.

3. Formed skills: gain support; to gain popularity and prestige; organize; convince; change yourself; be reliable; joke and understand humor; to know people, etc.

Thus, the effectiveness of the leadership competence is influenced by the set of personal qualities of the leader, which make up his potential, as well as professional competencies, motivational attitudes, managerial and interpersonal skills. The results of research have made it important for a leader to have another quality of leadership - emotional intelligence [6], which involves self-awareness, self-regulation, motivation to achieve, empathy, social skills.

References.

1. Spencer, L.M.Jr., and Spencer, S.M. (1993), Competence at work: Models for Superior Perfomance, London, UK.

2. Ritterfeld, U. Cody, M. and Vorderer, P. (2009), "Serious_Games: Mechanisms and effects”, available at: https://www.researchgate.net/publication/38079824_Multimodality_and_Interactivity_Connecting_Properties_of_Serio us_Games_with_Educational_Outcomes (Accessed 10 May 2021).

3. The Tuning project is the harmonization of educational structures in Europe (2021), available at: http://tuning.unideusto.org/tuningeu/images/sttories/template/General_Brochure_Ukrainian_version.pdf (Accessed 10 May 2021).

4. PGNIU (2018), "Development of management in Industry 4.0: the transition to cyber-physical organizations and the formation of their management systems", available at: http://www.psu.ru/files/docs/science/books/sborniki/razvitie-menedzhmenta-v-industrii-4.pdf (Accessed 10 May 2021).

5. Houlman, D. Boiatsys, R. and Makky, E. (2012), Emotsyonal'noe lyderstvo. Yskusstvo upravlenyia liud'my na osnove emotsyonal'noho yntellekta [Emotional leadership. The art of managing people based on emotional intelligence], Al'pyna Pablysher, Moscow, Russia.

6. Knysh, A.Ye. (2016), "Emotional intelligence of a leader in business", available at: http://repository.kpi.kharkov.ua/handle/KhPI-Press/27621 (Accessed 10 May 2021).

7. Zaverukha, N. (2021), "How useful are the descriptions of business processes", available at: https://buduysvoe.com/publications/chym-korysni-opysy-biznes-procesiv (Accessed 10 May 2021).

Bibliography. London.

1. Lile M. Spencer, Jr., PhD, Signe M. Spencer Competence at work: Models for Superior Perfomance, 1993,

2. Ritterfeld, U. Cody, M., Vorderer, P. 2009, Serious_Games: Mechanisms and effects. New York. p.6 [Электронный pecypc]:

URL: https://www.researchgate.net/publication/38079824_Multimodality_and_Interactivity_Connecting_Properties_of_Serio us_Games_with_Educational_Outcomes

3. The Tuning project is the harmonization of educational structures in Europe URL: http://tuning.unideusto.org/tuningeu/images/sttories/template/General_Brochure_Ukrainian_version.pdf

4. Развитие менеджмента в Индустрии 4.0: переход к киберфизическим организациям и формирование их систем управления: Материалы Междунар.науч.-практ. конф. (29 нояб. 2018 г.). [Электронный ресурс]: URL: http://www.psu.ru/files/docs/science/books/sborniki/razvitie-menedzhmenta-v-industrii-4.pdf

5. Гоулман Д., Бояцис Р., Макки Э. Эмоциональное лидерство. Искусство управления людьми на основе эмоционального интеллекта / Дэниел Гоулман, Ричард Бояцис, Энни Макки. - М.: Альпина Паблишер, 2012. $-301 \mathrm{c}$.

6. Емоційний інтелект лідера у сфері бізнесу: / А. Є. Книш. К.: 2016, 40с. [Электронный pecypc]: URL: http://repository.kpi.kharkov.ua/handle/KhPI-Press/27621

7. [Электронный ресурс]: URL: https://buduysvoe.com/publications/chym-korysni-opysy-biznes-procesiv

Стаття надійшла до редакиї̈ 13.05.2021 p. 